\title{
Alterations in Adipose Tissue during Critical Illness An Adaptive and Protective Response?
}

\author{
Lies Langouche ${ }^{1}$, Sarah Vander Perre ${ }^{1}$, Steven Thiessen ${ }^{1}$, Jan Gunst ${ }^{1}$, Greet Hermans ${ }^{2}$, André $^{\prime}$ Hoore $^{3}$, \\ Blerina Kola ${ }^{4}$, Márta Korbonits ${ }^{4}$, and Greet Van den Berghe ${ }^{1}$ \\ ${ }^{1}$ Department and Laboratory of Intensive Care Medicine, ${ }^{2}$ Department of Internal Medicine, ${ }^{3}$ Department of Abdominal Surgery, Katholieke \\ Universiteit Leuven, Belgium; and ${ }^{4}$ Department of Endocrinology, Barts and the London School of Medicine and Dentistry, Queen Mary University \\ of London, London, United Kingdom
}

\begin{abstract}
Rationale: Critical illness is characterized by lean tissue wasting, whereas adipose tissue is preserved. Overweight and obese critically ill patients may have a lower risk of death than lean patients, suggestive of a protective role for adipose tissue during illness. Objectives: To investigate whether adipose tissue could protectively respond to critical illness by storing potentially toxic metabolites, such as excess circulating glucose and triglycerides.

Methods: We studied adipose tissue morphology and metabolic activity markers in postmortem biopsies of 61 critically ill patients and 20 matched control subjects. Adipose morphology was also studied in in vivo biopsies of 27 patients and in a rabbit model of critical illness $(n=22)$.

Measurements and Main Results: Adipose tissue from critically ill patients revealed a higher number and a smaller size of adipocytes and increased preadipocyte marker levels as compared with control subjects. Virtually all adipose biopsies from critically ill patients displayed positive macrophage staining. The animal model demonstrated similar changes. Glucose transporter levels and glucose content were increased. Glucokinase expression was up-regulated, whereas glycogen and glucose-6-phosphate levels were low. Acetyl CoA carboxylase protein and fatty acid synthase activity were increased. Hormone-sensitive lipase activity was not altered, whereas lipoprotein lipase activity was increased. A substantially increased AMP-activated protein kinase activity may play a crucial role.

Conclusions: Postmortem adipose tissue biopsies from critically ill patients displayed a larger number of small adipocytes in response to critical illness, revealing an increased ability to take up circulating glucose and triglycerides. Similar morphologic changes were present in vivo. Such changes may render adipose tissue biologically active as a functional storage depot for potentially toxic metabolites, thereby contributing to survival.
\end{abstract}

Keywords: intensive care; adipose tissue; lipogenesis; lipolysis

Critically ill patients requiring prolonged intensive care are characterized by a profound decrease of lean body mass, evoking weakness and impairing rehabilitation, whereas, paradoxically, adipose tissue is preserved $(1,2)$. Remarkably, overweight (body mass index [BMI], 25-30 kg/m²) and obese (BMI, $\left.30-40 \mathrm{~kg} / \mathrm{m}^{2}\right)$ critically ill patients have recently been shown to

(Received in original form September 16, 2009; accepted in final form April 28, 2010) Supported by the Fund for Scientific Research, Flanders, Belgium (FWO), by the Research Council of the Katholieke Universiteit Leuven, and by long-term structural funding-Methusalem funding by the Flemish Government. L.L. is a postdoctoral fellow and J.G. is a Ph.D. fellow for the FWO.

Correspondence and requests for reprints should be addressed to Lies Langouche, Ph.D., Department and Laboratory of Intensive Care Medicine, Katholieke Universiteit Leuven, Belgium. E-mail: lies.langouche@med.kuleuven.be

This article has an online supplement, which is accessible from this issue's table of contents at www.atsjournals.org

Am J Respir Crit Care Med Vol 182. pp 507-516, 2010

Originally Published in Press as DOI: 10.1164/rccm.200909-1395OC on May 4, 2010

Internet address: www.atsjournals.org

\section{AT A GLANCE COMMENTARY}

What This Study Adds to the Field

Adipose tissue is substantially altered during critical illness, with an increased number of newly formed adipocytes, and is infiltrated by macrophages. These adipocytes have an increased ability to store glucose and triglycerides, possibly reducing detrimental effects of high levels of these circulating metabolites.

have a lower risk of death than patients with a normal BMI (3-5). Morbid obesity (BMI $\left.\geqslant 40 \mathrm{~kg} / \mathrm{m}^{2}\right)$, however, is an independent risk factor for death in the intensive care unit (ICU) (4). These observations suggest that adipose tissue may play a protective role during severe illness in the intensive care setting.

The primary metabolic role of adipose tissue is to store excess energy as triglycerides. This excess energy mainly originates from circulating lipids, which are taken up by adipocytes via action of lipoprotein lipase (LPL). A much smaller part of the stored triglycerides in adipocytes is de novo synthesized from circulating carbohydrates through lipogenesis (6). Critically ill patients suffer from dyslipidemia and hyperglycemia, partly due to increased hepatic lipogenesis (7) and gluconeogenesis (8). The severity of these alterations is associated with adverse outcome (9-11). Moreover, elevated circulating glucose (12-14) levels as well as high levels of triglycerides (15-17) can aggravate vital organ dysfunction during critical illness. We hypothesized that adipose tissue can respond to illness by increasing its storage properties for such circulating toxic metabolites, whereby it may enhance the chances of survival. To test this hypothesis, we obtained abdominal subcutaneous and omental adipose tissue biopsies from 61 nonsurviving critically ill patients with a BMI ranging from 16.3 to $31.2 \mathrm{~kg} / \mathrm{m}^{2}$, and compared these with biopsies from 20 matched control subjects undergoing elective abdominal surgery. More specifically, we studied adipose tissue morphology as well as its ability to take up and metabolize glucose and triglycerides. In addition, we studied adipose tissue morphological changes in response to critical illness in in vivo subcutaneous limb adipose tissue from 27 critically ill patients, and in the controlled setting of an animal model.

Some of the results of this study have been previously reported in the form of an abstract $(18,19)$.

\section{METHODS}

\section{Patients}

Patients were all enrolled in a large prospective, randomized, controlled study on the effects of intensive insulin therapy on outcome of 
critical illness (20). The detailed protocol of the study has been previously published (20). In brief, patients who had been randomly assigned to conventional insulin therapy received insulin only when glucose concentrations exceeded $215 \mathrm{mg} / \mathrm{dl}$, resulting in mean blood glucose of $157 \mathrm{mg} / \mathrm{dl}$ (hyperglycemia). Intensive insulin therapy targeted blood glucose levels between 80 and $110 \mathrm{mg} / \mathrm{dl}$, which resulted in mean blood glucose of $110 \mathrm{mg} / \mathrm{dl}$ (normoglycemia). Glucose control in each group was maintained according to protocol until ICU discharge or death. Postmortem biopsy samples of abdominal subcutaneous and omental adipose tissue were harvested within minutes after death from 61 long-stay patients of the 266 long-stay patients who died in the ICU, during weekdays, after consent, and when sufficient technical support was available. For postmortem tissue sampling, for academic purposes, each patient or his/her legal representative consented upon admission, via a hospital-wide information and consent procedure that requires active opting-out when not consenting. Opting-out remained possible until time of death. This strategy was approved by the K.U. Leuven Institutional Ethical Review Board (internal identification number ML 1820). The baseline and outcome characteristics of the critically ill patients from whom postmortem adipose tissue biopsies were collected are described in Table 1. From 27 long-stay patients, we collected qualitative in vivo subcutaneous adipose tissue biopsies from the vastus lateralis region on Day 15 of their ICU stay. The in vivo biopsies were taken after specific written informed consent from the patient or his/her legal representative. The baseline and outcome characteristics of the critically ill patients from whom in vivo adipose tissue biopsies were collected are described in the online supplement. All baseline characteristics were comparable for the two insulin treatment groups.

For comparison, we also collected abdominal subcutaneous and omental adipose tissue biopsy samples from demographically matched patients who were not critically ill, and who underwent elective abdominal surgery for restorative rectal resection (ML 2707; see online supplement). These patients provided written informed consent prior to the procedure.

The protocols and all consent forms were approved by the K.U. Leuven Institutional Ethical Review Board (internal identification numbers ML 1820 and ML 2707). All tissue samples were snap frozen in liquid nitrogen and stored at $-80^{\circ} \mathrm{C}$ until analysis.

\section{Gene and Protein Expression}

Messenger RNA was isolated and cDNA quantified in real time as described previously (12). Data are expressed normalized to glyceraldehyde 3-phosphate dehydrogenase expression and as a fold change of the mean of the control patients. A complete list of primers and probes is provided in the online supplement. Western blots were performed as described in the online supplement.

\section{Glucose and Triglyceride Tissue Content}

Spectrophotometric assays were used to quantify the tissue levels of glucose, glucose-6-phosphate, glycogen, and glycerol levels, the latter in Bligh-Dyer extracts of tissues (21).

\section{Fatty Acid Synthase, Lipase, and AMP-activated Protein Kinase Activity Assays}

For fatty acid synthase (FAS) activity, reaction mix containing reduced nicotinamide adenine dinucleotide phosphate, acetyl CoA, malonyl CoA, and [2-14C]malonyl CoA was added to tissue homogenates. After incubation and extraction of the fatty acids, incorporation of [2-14C]malonyl CoA was analyzed by scintillation counting. The kinase assay for AMP-activated protein kinase (AMPK) activity has been previously described (22), and was determined by the amount of ${ }^{32} \mathrm{P}$ incorporation into an AMPK substrate. The detailed protocol is described in the online supplement. Total lipase activity was determined with the commercial Confluolip kit (Progen Biotechnik, Heidelberg, Germany).

\section{Circulating Parameters}

Serum levels of insulin were measured by ELISA (Invitrogen, Merelbeke, Belgium). Serum triglyceride levels were measured by a spectrophotometric assay, as described previously here. Samples were all run in duplicate.

\section{Rabbit Model of Critical Illness}

The experiment was performed in our previously validated rabbit model of prolonged critical illness, which has shown to mimic the characteristic endocrine, biochemical, and immunological disturbances

TABLE 1. CHARACTERISTICS OF PATIENTS FROM WHOM POSTMORTEM BIOPSIES WERE STUDIED

\begin{tabular}{|c|c|c|c|}
\hline Characteristics & $\begin{array}{l}\text { Conventional Insulin } \\
\quad(n=33)\end{array}$ & $\begin{array}{l}\text { Intensive Insulin } \\
\quad(n=28)\end{array}$ & $P$ Value \\
\hline Male sex, no. & 19 & 17 & 0.80 \\
\hline Age, $\mathrm{yr}^{*}$ & $64 \pm 17$ & $70 \pm 11$ & 0.14 \\
\hline BMI, $\mathrm{kg} / \mathrm{m}^{2 *}$ & $23.5 \pm 3.6$ & $24.8 \pm 3.3$ & 0.12 \\
\hline History of diabetes, no. & 4 & 5 & 0.53 \\
\hline APACHE-II score on admission ${ }^{\dagger}$ & $26(22-35)$ & $28(20-32)$ & 0.98 \\
\hline SOFA score on admission ${ }^{\dagger}$ & $10(7-14)$ & $8(5-12)$ & 0.10 \\
\hline Blood glucose on admission, $\mathrm{mg} / \mathrm{dl}^{*}$ & $167.5 \pm 73.7$ & $174.5 \pm 75.9$ & 0.71 \\
\hline Days in $\mathrm{ICU}^{\dagger}$ & $10(6-21.5)$ & $10(7-15.5)$ & 0.95 \\
\hline Diagnostic group upon admission & & & 0.69 \\
\hline Cardiovascular & 3 & 2 & \\
\hline Gastrointestinal or liver & 4 & 1 & \\
\hline Hematologic or oncologic & 7 & 3 & \\
\hline Neurologic & 1 & 2 & \\
\hline Renal & 1 & 1 & \\
\hline Respiratory & 15 & 15 & \\
\hline Other & 2 & 4 & \\
\hline Cause of death in ICU & & & 0.37 \\
\hline Severe brain damage & 2 & 0 & \\
\hline Respiratory failure & 13 & 13 & \\
\hline Therapy resistant septic shock/cardiovascular collapse & 8 & 6 & \\
\hline Persistent MOF after septic or SIRS induced shock & 10 & 9 & \\
\hline CRP level on biopsy day, $\mathrm{mg} / \mathrm{L}^{\dagger}$ & $178(61-235)$ & $152(73-268)$ & 0.8 \\
\hline Time lag, time of death to biopsy preservation, $\min ^{*}$ & $14.5 \pm 8.3$ & $19.5 \pm 12.7$ & 0.07 \\
\hline
\end{tabular}

Definition of abbreviations: APACHE = Acute Physiology and Chronic Health Assessment Evaluation; BMI = body mass index; $\mathrm{CRP}=\mathrm{C}$-reactive protein; ICU = intensive care unit; SOFA = Sequential Organ Failure Assessment (higher scores indicate more severe illness); MOF = Multiple Organ Failure; SIRS = systemic inflammatory response syndrome.

* Data presented are mean \pm SD.

${ }^{\dagger}$ Data presented are median (interquartile range) 
of human critical illness (23). For the purpose of this study, the protocol was slightly modified. We sampled subcutaneous adipose tissue biopsies before randomization and again after 7 days. Rabbits were randomized into two groups: 7 sham-operated animals, and 15 critically ill animals. The detailed protocol is described in the online supplement.

\section{Adipocyte Morphology}

For quantification of adipocyte size, sections were stained with hematoxylin and eosin, and adipocyte size was determined by computer image analysis. For macrophage evaluation, sections were stained with a primary anti-macrophage antibody, and counterstained with hematoxylin. Adipose tissue sections were evaluated in a blinded fashion. A detailed protocol is described in the online supplement.

\section{Statistical Analysis}

We used analysis of variance and unpaired $t$ test for normally distributed data and the nonparametric Kruskal-Wallis and MannWhitney U test when data appeared to be not normally distributed. We used $\chi^{2}$ test for comparison of proportions. We used Wilcoxon's signed ranked paired analysis for the rabbit data. The significance of correlations was assessed by calculation of the Pearson $(r)$ correlation coefficient. $P$ values of 0.05 or less were considered statistically significant.

\section{RESULTS}

\section{Adipocyte Morphology and Macrophage Staining}

Adipocyte cell size of both subcutaneous and omental adipose tissue of critically ill patients was smaller than that of healthy control subjects. This was revealed by a smaller median cell area (Figure 1A). The fraction of small adipocytes in postmortem subcutaneous adipose tissue (defined as cell area below the 25th percentile of those in healthy control subjects $\left[400 \mu \mathrm{m}^{2}\right]$ ) was increased to $33.4 \%$ in biopsies from critically ill patients $(P=$ $0.008)$. A comparable amount $(30.5 \%$, ranging from 21.8 to $43.9 \%$ ) of small adipocytes was observed in in vivo harvested subcutaneous adipose tissue biopsies $(n=27)$. In omental postmortem adipose tissue, $41.4 \%$ of the adipocytes in the critically ill biopsies were small (defined as cell area smaller than the 25th percentile of the healthy control subjects $\left[500 \mu \mathrm{m}^{2}\right]$ ), which was significantly more than in control subjects $(P<0.003)$. Total protein content per gram tissue was similar in critically ill and control biopsies (see the online supplement). Gene expression levels of perilipin, a protein coating the lipid droplet in adipocytes, was lower in subcutaneous and omental postmortem adipose tissue of critically ill patients than in control subjects (Figure 1B). In contrast, protein levels of the pre-adipocyte marker, preadipocyte factor (Pref)-1, was higher in biopsies from critically ill patients than in control subjects (Figure 1C). We stained sections of adipose tissue for the macrophage marker, CD68 (Figure 1D). In both subcutaneous adipose tissue and omental adipose tissue biopsies of healthy control subjects, twothirds stained negative, whereas, in one-third of the biopsies, some positive staining was present. This was in sharp contrast with the postmortem biopsies from critically ill patients, where $100 \%$ (subcutaneous adipose tissue, $P<0.0001$ ) and 95\% (omental adipose tissue, $P<0.0001)$ stained positive for CD68. Furthermore, in two-thirds of the biopsies of critically ill patients,
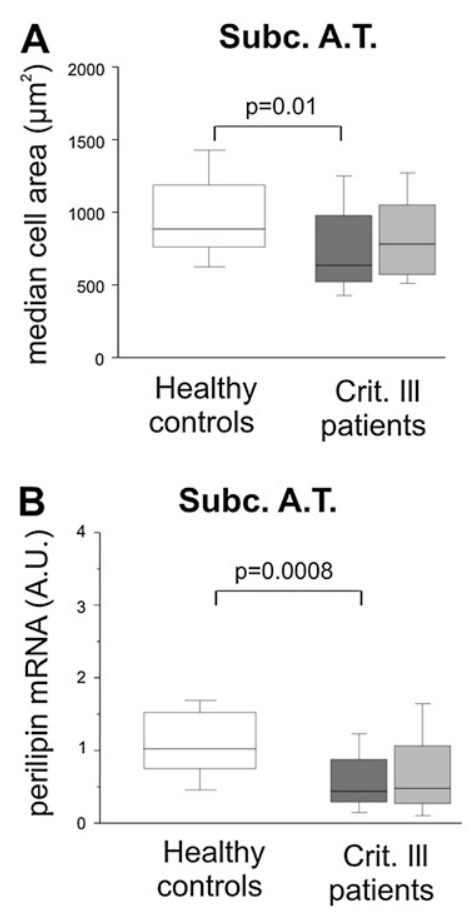
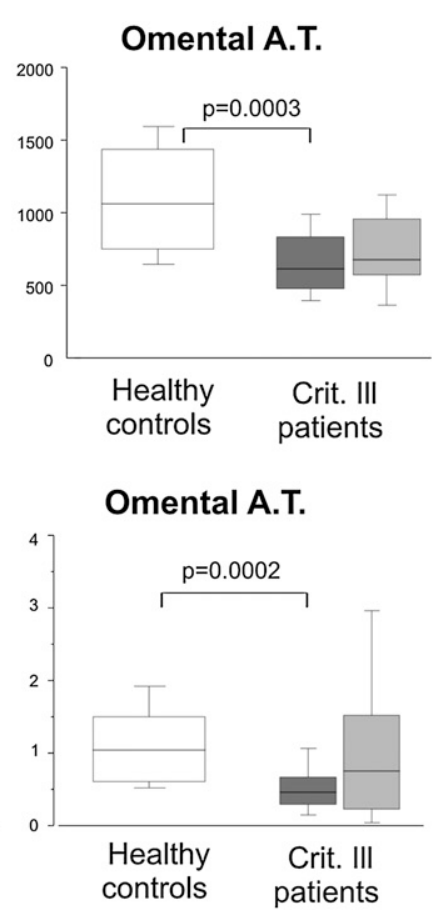
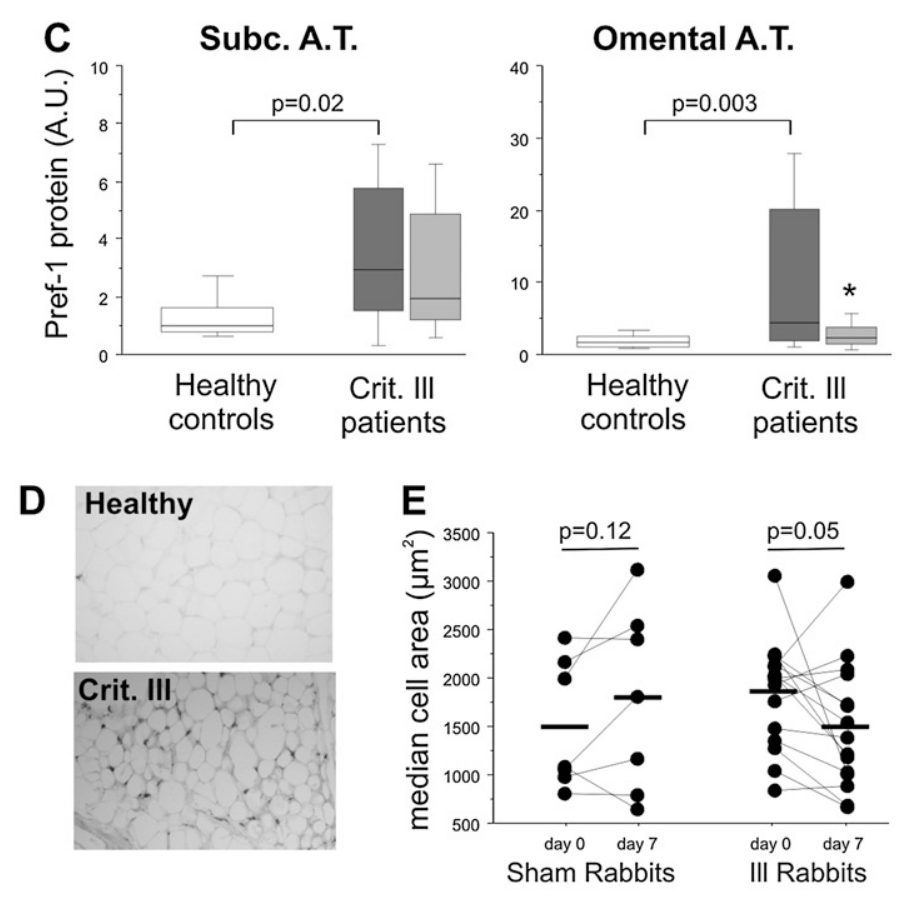

Figure 1. Human adipocyte morphology in critical illness in postmortem biopsies $(A-D)$ and paired in vivo analysis of adipocyte cell size in a rabbit model of critical illness $(E)$. (A) Median adipocyte cell area, $(B)$ mRNA adipose tissue (A.T.) levels of perilipin, $(C)$ protein A.T. levels of preadipocyte factor (Pref)-1, (D) CD68 macrophage staining. Data boxes represent median and interquartile range; whiskers represent the 10th and the 90th percentiles. White boxes represent healthy control subjects undergoing elective surgery $(n=20)$; dark gray boxes represent critically ill patients who received conventional insulin therapy $(n=33)$; light gray boxes represent critically ill patients who received intensive insulin therapy $(n=28)$. Lines and $P$ values indicate difference between healthy and conventionally treated critically ill patients. *Different from conventional insulin therapy $(P \leqslant$ 0.05). A.U. = arbitrary units. (E) Paired median adipocyte cell area in sham-treated healthy rabbits $(n=7)$ and critically ill rabbits $(n=15)$. Subcutaneous A.T. biopsies were taken at Day 0 (before randomization) and after 7 days. At Day 7, A.T. biopsies from two healthy rabbits and eight sick rabbits stained positive for macrophages. A.U. = arbitrary units; Subc. = subcutaneous. 
the number of $\mathrm{CD}^{+} 8^{+}$cells was high. $\mathrm{CD}^{+} 8^{+}$staining was also observed in the 27 in vivo subcutaneous limb adipose tissue biopsies of prolonged critically ill patients. All of the 15 in vivo biopsies of conventional patients stained positive for macrophages, and, in $73 \%$ of these, the number of positively staining cells was high. From the 12 in vivo biopsies obtained from patients under intensive insulin treatment, 11 stained positive for macrophages, and, in $50 \%$ of these, the number of positively staining cells was high.

We also performed a control experiment in our rabbit model of critical illness, in which we compared 15 ill rabbits with 7 shamoperated rabbits. This model allowed us to sample adipose tissue before and after 7 days of illness in the same animal. We could demonstrate a decrease in median cell size in the ill rabbits compared with the healthy rabbits (Figure 1E), whereas the total weight of the isolated fat pad did not decrease (median weight, $4.1 \mathrm{~g}$ for both; $P=0.9$ ), indicative of an increased cell number. We also measured an increase in macrophage staining in the biopsies from ill rabbits versus those from healthy rabbits on Day 7 (increase from $29 \%$ of biopsies with RAM $11^{+}$staining in shamoperated animals to $53 \%$ in ill rabbits).

\section{Storage Properties of Adipose Tissue during Critical IIIness}

We first studied the ability of the adipose tissue to take up and metabolize glucose into fatty acids in patients with prolonged critical illness as compared with control subjects. In postmortem subcutaneous and omental adipose tissue of critically ill patients, mRNA and protein levels of the insulin-independent glucose transporters, GLUT1 and GLUT3, but not the insulindependent GLUT4, were strongly elevated (see Figures 2A-2B and the online supplement). The tissue content of glucose in postmortem subcutaneous and omental adipose tissue of critically ill patients was higher than in control subjects (Figure 2D), but was lowered by intensive insulin therapy. These differences in the adipose tissue glucose content among the groups mimicked the differences in plasma glucose (Figure 2E).

When glucose enters the cell, it is phosphorylated by the enzyme, hexokinase, to glucose-6-phosphate, which can, in turn,
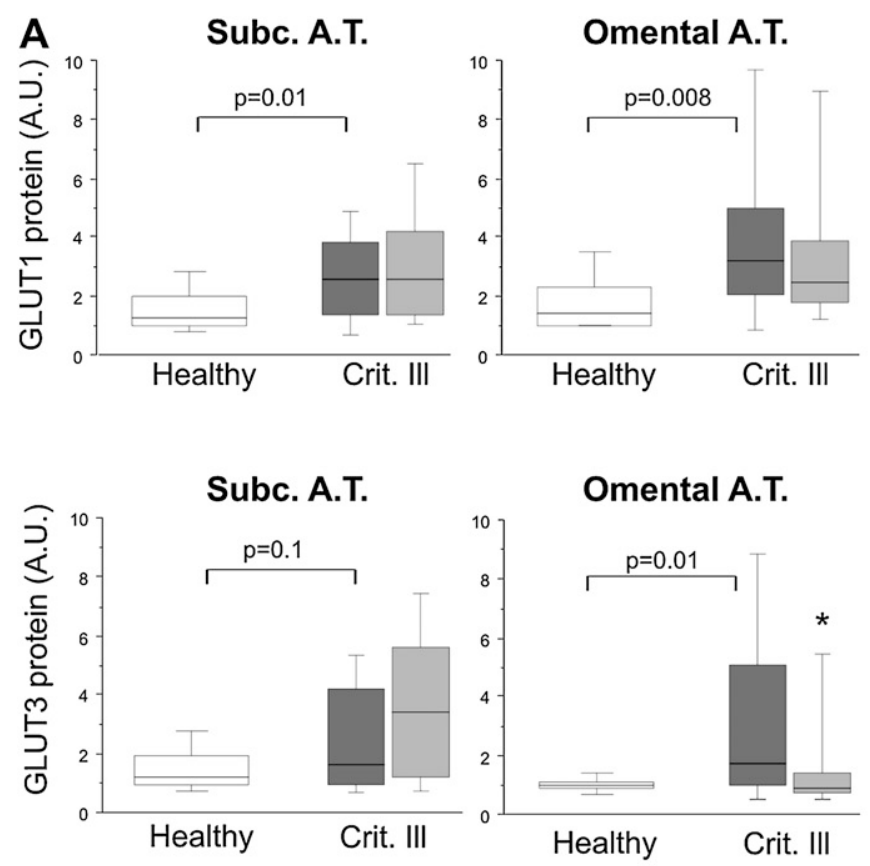

B

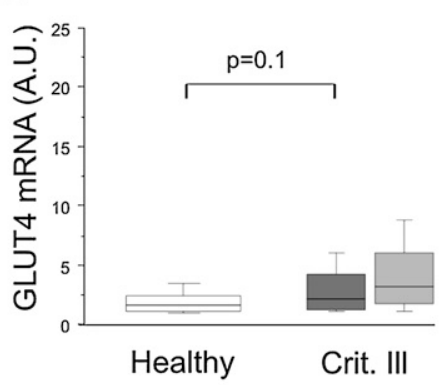

Omental A.T.

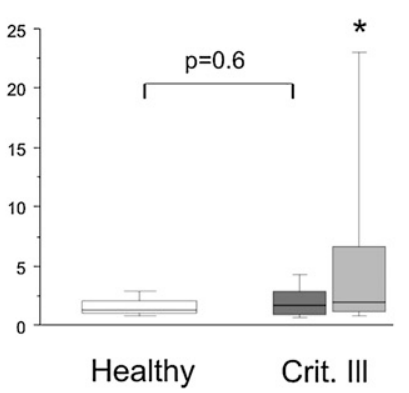

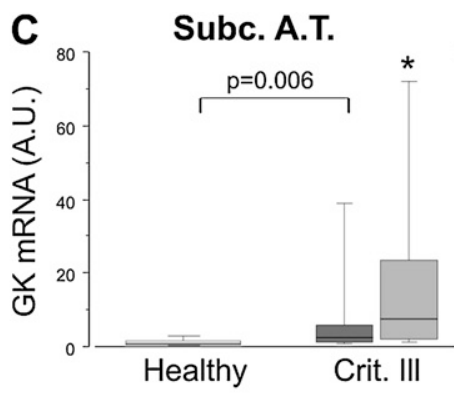
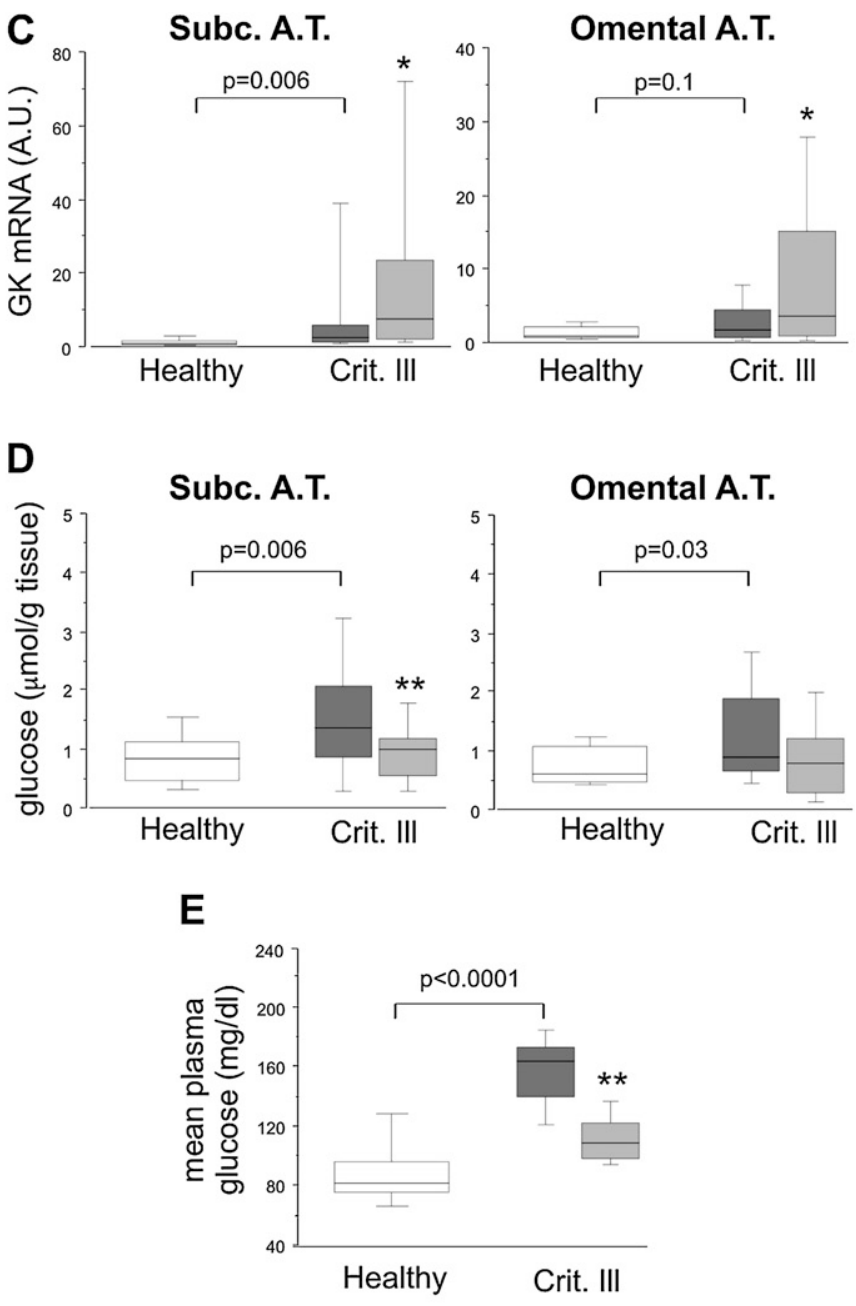

Figure 2. Glucose uptake in postmortem adipose tissue (A.T.) of critically ill patients. Human A.T. levels of $(A)$ protein of GLUT1 and GLUT3, (B) mRNA of GLUT4, $(C)$ mRNA of glucokinase, $(D)$ tissue levels of glucose, and $(E)$ mean daily plasma glucose levels. Data boxes present median and interquartile range; whiskers represent the 10th and the 90th percentiles. White boxes represent healthy control subjects undergoing elective surgery $(n=20)$; dark gray boxes represent critically ill patients who received conventional insulin therapy $(n=33)$; light gray bars represent critically ill patients who received intensive insulin therapy $(n=28)$. Lines and $P$ value indicate difference between healthy and conventionally treated critically ill patients. *Different from conventional insulin therapy $(P \leqslant 0.05)$; ${ }^{* *}$ different from conventional insulin therapy $(P \leqslant 0.01)$. A.U. $=$ arbitrary units; Subc. $=$ subcutaneous. 
be stored as glycogen, or further metabolized to pyruvate. In healthy control subjects, we documented very low glucokinase gene expression levels compared to the much higher levels in postmortem subcutaneous adipose tissue of critically ill patients (Figure 2C). Hexokinase 1 and 2 expression in the critically ill was not different from control subjects (see the online supplement). The tissue levels of glucose-6-phosphate and of glycogen were hardly detectable in postmortem subcutaneous and omental adipose tissue of both critically ill patients and control subjects.

Because, in the adipose tissue biopsies, glucose was not stored as glycogen, we studied lipogenesis as the alternative metabolic destiny of glucose. When glucose is metabolized into fatty acids, the glycolytic end product, pyruvate, is metabolized to acetyl CoA, which is subsequently turned into malonyl CoA by the enzyme, acetyl CoA carboxylase (ACC). In postmortem subcutaneous adipose tissue of critically ill patients, total levels of ACC were indeed several fold higher than in healthy control subjects (Figure 3A). In addition, the enzymatic activity of FAS, another lipogenic enzyme, was strongly up-regulated (Figure 3B). Expression of stearoyl CoA desaturase, involved in the biosynthesis of monounsaturated fatty acids, was also higher in postmortem subcutaneous adipose tissue of critically ill patients (Figure 3C). Similar changes in these lipogenic enzymes were observed in the omental adipose tissue biopsies of critically ill patients (Figures 3A-3C).

The other important metabolic storage process that takes place in adipose tissue is lipolysis. LPL is responsible for hydrolysis and uptake of circulating triglycerides. On the other hand, activated hormone-sensitive lipase (HSL) is the ratelimiting enzyme in the hydrolysis and the release of stored adipose triglycerides back into the bloodstream. Circulating triglyceride levels were increased in critical illness (Figure 4B). In both omental and subcutaneous postmortem adipose tissue homogenates of critically ill patients, levels of activated (Ser563 phosphorylated) HSL remained equal compared with that of healthy control subjects (Figure 3D). In contrast, protein levels of LPL were increased several fold in both omental and subcutaneous adipose tissue homogenates of critically ill patients (Figure 3E). Total lipase activity was also increased several fold in postmortem omental and subcutaneous adipose tissue homogenates of critically ill patients (Figure 3F), and correlated with LPL levels $(r=0.279, P=0.03$ in omental adipose tissue), but not with phosphorylated HSL.
A

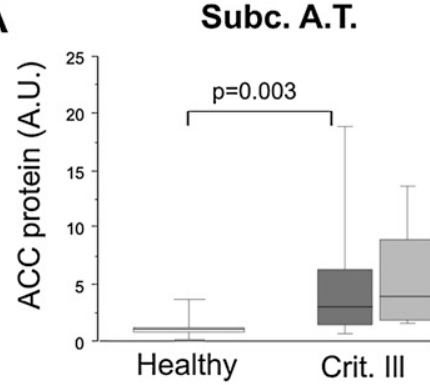

B

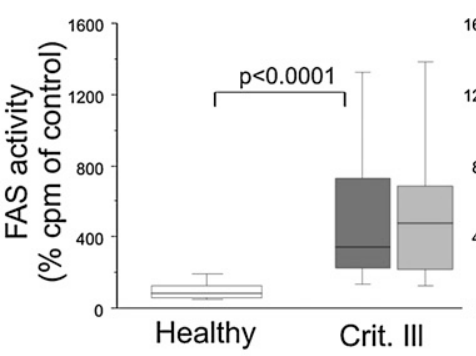

C

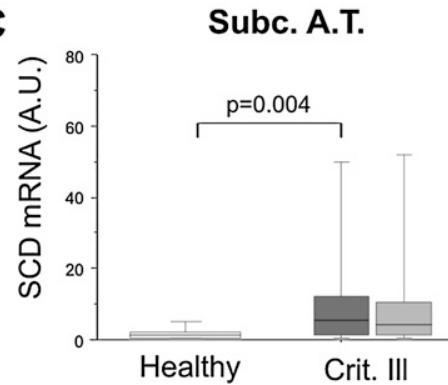

Omental A.T.

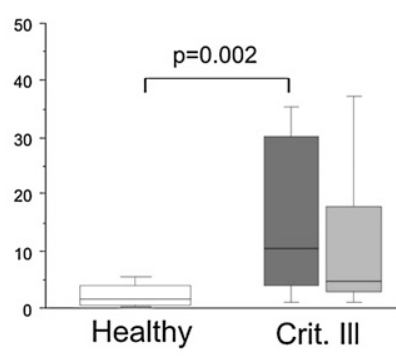

Omental A.T.

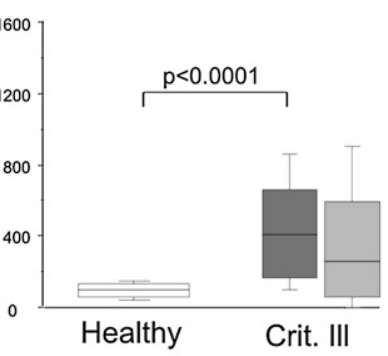

Omental A.T.

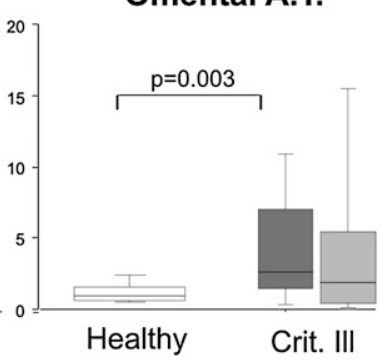

D

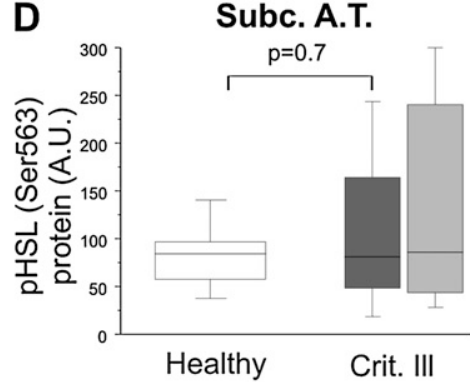

E

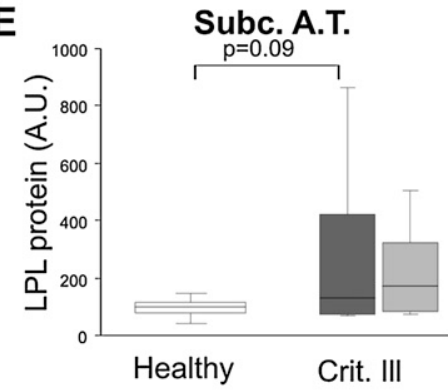

Subc. A.T.

F

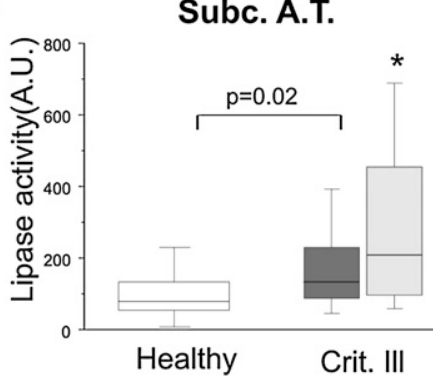

Omental A.T.

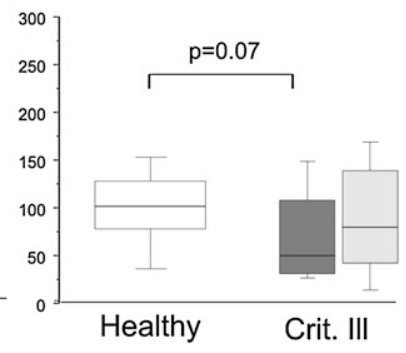

Omental A.T.

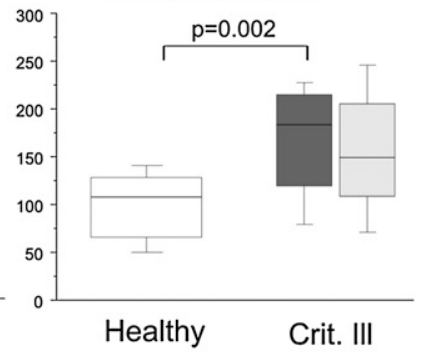

Omental A.T.

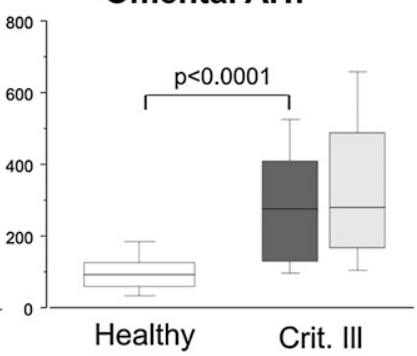

Figure 3. Lipogenesis and lipolysis in postmortem adipose tissue (A.T.) of critically ill patients. Human A.T. levels of $(A)$ acetyl CoA carboxylase protein, $(B)$ fatty acid synthase activity, $(C)$ stearoyl CoA desaturase mRNA, $(D)$ phospho(Ser563) hormone-sensitive lipase protein, $(E)$ protein of lipoprotein lipase, and $(F)$ lipase activity. Data boxes present median and interquartile range; whiskers represent the 10th and the 90 th percentiles. White boxes represent healthy control subjects undergoing elective surgery $(n=20)$; dark gray boxes represent critically ill patients who received conventional insulin therapy $(n=33)$; light gray bars represent critically ill patients who received intensive insulin therapy ( $n=28)$. Line and $P$ value indicate difference between healthy and conventionally treated critically ill patients. * Different from conventional insulin therapy $(P<0.05)$. A.U. $=$ arbitrary units; Subc. $=$ subcutaneous. 
A

Subc. A.T.

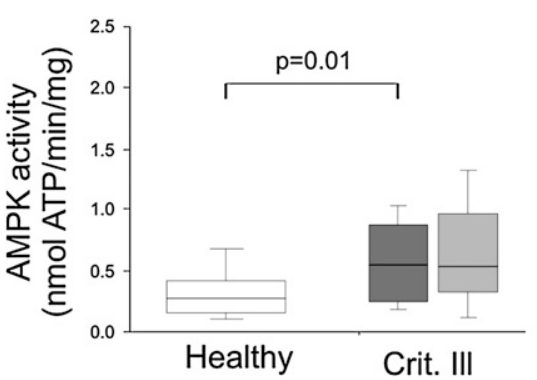

B

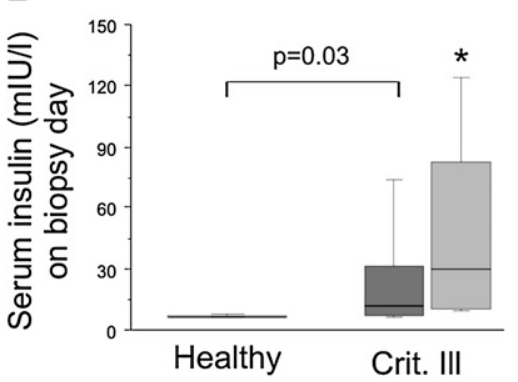

Omental A.T.
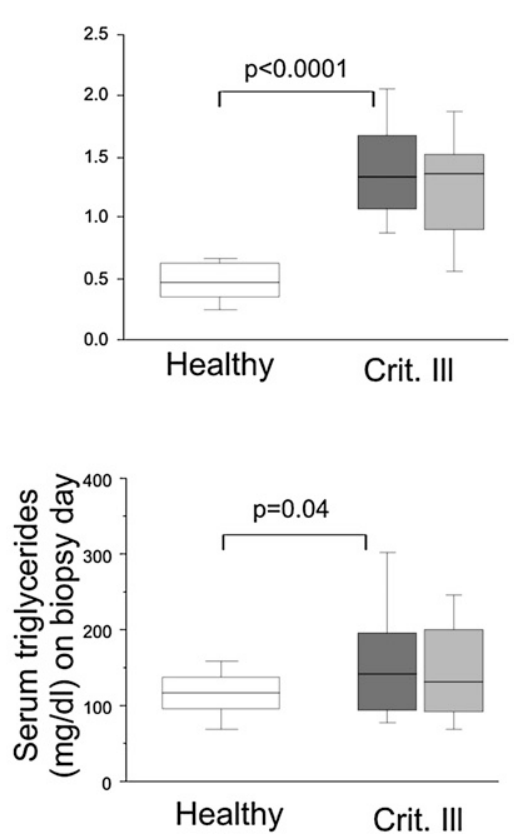

C

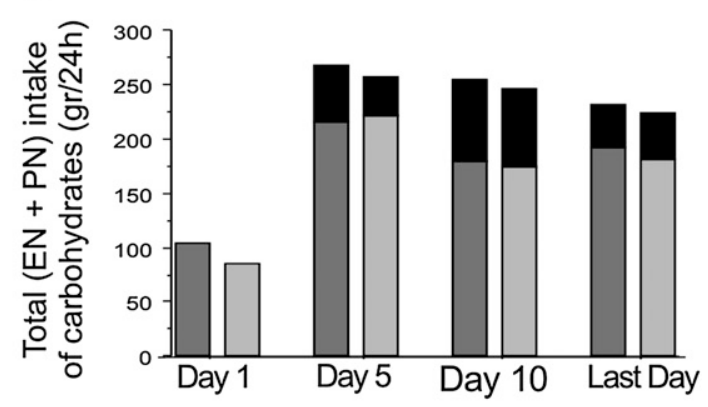

Figure 4. Mechanism behind altered substrate handling in postmortem adipose tissue (A.T.) of critically ill patients. (A) Human A.T. activity levels of AMP-activated protein kinase (AMPK), $(B)$ serum insulin and serum triglyceride levels on biopsy day, $(C)$ daily intake of enteral and parenteral feeding during intensive care unit (ICU) stay. Data boxes represent median and interquartile range; whiskers represent the 10th and the 90 th percentiles. Open boxes represent healthy control subjects undergoing elective surgery $(n=20)$; light gray boxes represent critically ill patients who received conventional insulin therapy $(n=33)$; dark gray boxes represent critically ill patients who received intensive insulin therapy $(n=28)$. Lines and $P$ value indicate difference between healthy and conventionally treated critically ill patients. *Different from conventional insulin therapy $(P \leqslant$ 0.05). (C) Gray bars represent the daily intake of parenteral feeding in critically ill patients who received conventional insulin therapy (light gray; $n=$ 33) and intensive insulin therapy (dark gray; $n=28$ ), and black bars represent the daily enteral intake. The upper panel represents the administered carbohydrates; the lower panel represents the administered lipids. Data are presented as mean total daily (24-h) intake on day of admission, Day 5, Day 10, and last day of ICU stay. EN = enteral; PN = parenteral; Subc. = subcutaneous.

\section{Impact of Intensive Insulin Therapy on Adipose Tissue Morphology and Studied Metabolic Pathways}

Critically ill patients in both the conventional and the intensive insulin treatment arms revealed elevated circulating glucose and insulin levels as compared with control subjects, typical for the insulin resistance associated with severe illness. Blood glucose levels were lower (Figure 2E), as per protocol, and circulating insulin levels were higher in intensive insulin-treated patients, who received higher doses of insulin as compared with patients in the conventional insulin group (Figure 4B).

The intensity of insulin therapy during critical illness, however, only had a relatively small effect on adipocyte morphology and on the studied storage parameters tested. Intensive insulin therapy reduced the incidence of positive macrophage staining in subcutaneous adipose tissue (from 64 to $53 \%$ in omental, and from 66 to $27 \%$ in subcutaneous adipose tissue). Intensive insulin therapy reduced the glucose content in postmortem adipose tissue, as well as the expression levels of Pref- 1 and GLUT-3 in omental adipose tissue (Figures $1 \mathrm{C}$ and 2A), elevated the expression levels of GLUT-4 in omental adipose tissue (Figure 2B), and increased the expression levels of glucokinase in postmortem subcutaneous and omental adipose tissue (Figure 2C).

\section{Mechanism behind Altered Substrate Handling}

The energy-sensing enzyme, AMPK, usually activated by a high AMP:ATP ratio, was clearly activated in subcutaneous and omental adipose tissue of critically ill patients as compared with control subjects (Figure 4A). AMPK increases glucose uptake and glycolysis, but can also inactivate ACC by phosphorylation. Indeed, protein levels of phosphorylated ACC were increased in postmortem adipose tissue of critically ill patients (in subcutaneous adipose tissue: median [interquartile range], 6.8 [2.8-11.9] in critically ill patients versus 1 [0.4-3.3] in control subjects; $P=0.0002$; in omental adipose tissue: 5.9 [2.7-12.7] in critically ill patients versus $1.4[0.7-3.1]$ in control subjects; $P=0.04)$. The ratio of phosphorylated ACC to total ACC levels was not different between critically ill patients and control subjects ( $P=0.6$ for subcutaneous adipose tissue and $P=0.5$ for omental adipose tissue).

One might hypothesize that the artificial enteral and parenteral feeding used for critically ill patients may affect lipogenesis and lipolysis. Although the sum of daily enteral and parenteral amounts of carbohydrate and lipids at no time exceeded the required daily amounts (Figure $4 \mathrm{C}$ ), the ICU patients included in this study all received at least partial parenteral feeding during ICU stay, due to the type and severity of illness (patients from whom biopsies were studied were all nonsurvivors, with high onadmission Acute Physiology and Chronic Health Assessment Evaluation II scores). However, the studied parameters in subcutaneous and omental adipose tissue did not correlate with the daily parenteral or total caloric intake, except for FAS activity in omental adipose tissue, which correlated with the mean total caloric intake $\left(r^{2}=0.251\right)$ (see the online supplement).

The patient population from which we were able to collect postmortem adipose tissue biopsies has a mean BMI of 25 , 
ranging from 16.3 to 31.2 . The tested 61 biopsies were predominantly from normal to overweight patients: $33(54 \%)$ of the patients had a normal BMI, 22 (36\%) were overweight, and only $3(5 \%)$ were obese. Only omental median adipocyte cell size showed a biologically relevant correlation with BMI. This suggests that adipocytes in either normal or overweight critically ill patients may act identically.

\section{DISCUSSION}

Our data suggest that adipose tissue is substantially altered during critical illness, with an increased number of newly formed adipocytes and macrophage infiltration. The larger number of small adipocytes appear to have an increased ability to take up and metabolize glucose and store triglycerides, a process in which an increased activity of the energy-sensing enzyme, AMPK, could partially play a role. Taking into account the clear association between both hyperglycemia and dislipidemia and mortality observed in critical illness, these alterations may present an adaptive and protective response.

We observed a smaller median adipocyte cell size and an increase in number of small adipocytes in critically ill patients, indicating a higher number of newly formed adipocytes. Although its function is not unequivocally clear, the observed elevation in the preadipocyte marker, Pref-1, also may be indicative of an up-regulated differentiation from mesenchymal stem cells into preadipocytes, and further into full functional adipocytes. However, Pref- 1 has not only been suggested to be a potentiator of adipogenesis in mesenchymal cells $(24,25)$, but also to maintain the undifferentiated state of preadipocytes $(26$, 27). As we observed a higher number of small-sized adipocytes together with higher levels of Pref-1, our results could be interpreted as increased adipogenesis.

The high number of CD68 positive-stained cells in all studied adipose tissue biopsies of critically ill patients, obtained from both the subcutaneous and the omental site, postmortem and in vivo, is striking. CD68 is recognized to be a specific macrophage marker (28). Macrophage accumulation in adipose tissue has been demonstrated in obesity $(29,30)$, and systemic hypoxia has been associated with increased inflammation in adipose tissue (31). Several reasons for macrophage accumulation in adipose tissue of obese people have been proposed. It has been suggested that hypertrophic or expanding adipocytes may produce chemotactic signals, leading to macrophage recruitment in an attempt to limit adipose tissue expansion (32-34). The other suggested mechanism involves oxidative stress in the endothelium due to increased glucose delivery. Endothelial injury in the adipose tissue could attract inflammatory cells, such as macrophages, further exacerbating local inflammation (35). Why critical illness is associated with increased infiltration of macrophages is not clear. Unlike in otherwise healthy obese people, we observed smaller adipocytes during critical illness. Only rarely did we observe large necrotic adipocytes surrounded by foaming macrophages. The hyperglycemic environment of critical illness, which has been shown to evoke endothelial injury (12), may play a role. Indeed, patients in the conventional insulin arm revealed more pronounced macrophage infiltration than patients in the intensive insulin arm. However, expanding preadipocytes have also been shown to produce chemotactic signals (36). In addition, macrophages may also originate from transdifferentiation of preadipocytes into macrophage-like cells (37). Hence, the macrophage accumulation in critical illness could be, in part, a consequence of increased adipogenesis. Studies on the acute phase of critical illness showed high levels of inflammatory markers, but unaltered macrophage markers $(38,39)$, suggesting that the macrophage accumulation that we observe is not part of the acute stress response, but part of the complex hypermetabolic condition of prolonged critical illness.

The larger number of small adipocytes appeared to have an increased ability to take up and metabolize glucose into fatty acids and to take up and store circulating triglycerides. Adipose tissue normally takes up glucose through the insulin-dependent glucose transporter, GLUT4 (40). We have now observed that the insulin-independent glucose transporters, GLUT1 and GLUT3, in adipose tissue were highly up-regulated during critical illness. This may evoke an increased influx of glucose into adipose tissue. Indeed, these high-affinity transporters have a $K_{\mathrm{m}}$ below the observed range of blood glucose in the critically ill, so an increase in cell surface expression will affect the rate of glucose uptake into the cells. This increase in glucose transporters might be triggered by metabolic stress, such as cellular hypoxia, but also by hyperglycemia, insulin, or cytokines (41-43). Once transported into the cell, glucose becomes phosphorylated to glucose-6-phophate by hexokinase. We measured an increased expression of the lowaffinity glucokinase, but not of the high-affinity hexokinase I and II. In contrast to hexokinase I and II, glucokinase is not inhibited by its end product, glucose-6-phophate (41), whereby it contributes to rapid phosphorylation and trapping of glucose into the cell. We measured only very low levels of glucose-6-phophate and glycogen in the adipose tissue, indicating that glucose-6-phophate is further metabolized. In normal conditions, glucose-6-phophate would be oxidized in the Krebs cycle. The increased activity of the lipogenic enzymes, ACC, FAS, and stearoyl CoA desaturase, in the critically ill, however, may point to an increased metabolization of glucose into fatty acids (44).

Although adipose tissue can synthesize free fatty acids de novo, free fatty acids for lipid storage are preferentially provided by LPL-mediated hydrolysis of circulating triglyceriderich lipoproteins. We could indeed demonstrate that adipose tissue of critically ill patients showed a markedly increased LPL protein level and lipase activity. Furthermore, LPL is an important marker for adipocyte differentiation with increased LPL expression when preadipocytes differentiate (45). Contrary to the uptake of circulating triglycerides, HSL will hydrolyze and release stored triglycerides back into the circulation. In the studied biopsies from critically ill patients, we observed no alteration in the level of activated HSL.

All the studied ICU patients received intravenous feeding during ICU stay. Although the sum of enteral and parenteral feeding components did not exceed the reference daily intake (46), one could expect intravenously administered glucose and lipids to cause increased lipogenesis or lipolysis in adipose tissue. However, we did not observe a correlation between the mean total or intravenous caloric intake and the studied glycolytic, lipogenic, and lipolytic parameters, which appears to exclude a prominent role of artificial feeding in explaining our observations. In addition, it has been shown previously that, as compared with hepatic lipogenesis, human adipose tissue lipogenesis is less responsive to dietary carbohydrates $(47,48)$.

A likely explanation for the observed shift in metabolization is the hypoxic condition of critical illness. Critically ill patients suffer from reduced oxygen pressure and oxygen blood content, causing cellular hypoxia in different tissues (49). The cellular pathways activated by hypoxic stress, such as the hypoxiainducible factor and AMPK pathway, shut down energy-consuming pathways that are not acutely needed for cell survival. Activation increases the uptake of glucose and glycolysis, resulting in pyruvate production $(50,51)$, but, in addition, HSL activity is attenuated (52) and fatty acid uptake is increased $(53,54)$. We clearly demonstrated increased AMPK activity in adipose tissue of critically ill patients. A lower oxygen availability in adipose tissue during critical illness may, thus, not only stimulate uptake 
of glucose, but also impair complete glucose oxidation, with a shift to fatty acid synthesis. On the other hand, this mechanism may attenuate hydrolysis of stored triglycerides, but stimulate uptake of circulating fatty acids. Unfortunately, we were not able to quantify possible hypoxia in the adipose tissue; thus, these conclusions remain speculative. The high levels of circulating insulin that are present in critically ill patients are also a possible trigger for increased metabolization of glucose into fatty acids (11). Insulin action in adipose tissue indeed involves stimulation of glucose uptake, increase of glucokinase expression, and stimulation of FAS expression and activity $(41,55,56)$. Insulin has been shown to reduce lipid oxidation by increasing intracellular glucose flux (57). Insulin inhibits HSL activity, but stimulates LPL levels and activity, thereby reducing hydrolysis of stored triglycerides and increasing uptake of circulating triglycerides (58-60). In addition, small-sized adipocytes have been demonstrated to be more insulin sensitive and display increased lipogenesis (61-63). The studied patients were all enrolled in a large, randomized, controlled trial on glycemic control in the medical ICU (20). Patients under intensive insulin therapy received high doses of insulin to maintain normal blood glucose levels, whereas patients who had been randomly assigned to conventional insulin therapy received insulin only when glucose concentrations exceeded $215 \mathrm{mg} / \mathrm{dl}$. Although patients under intensive insulin therapy received much higher doses of insulin throughout the stay in the ICU, circulating insulin levels were not that different. We demonstrated earlier that this is primarily due to a lowered endogenous insulin production in the intensive insulin therapy group, as well as an effect on insulin sensitivity (64, $65)$. The clearly elevated circulating insulin levels in both insulin therapy groups may explain the minor differences in the metabolic activity of the adipose tissue. A third possible mediator in the observed changes might be the typical uniform suppression of the neuroendocrine axes in prolonged critical illness (66). Indeed, thyroid-stimulating hormone normally stimulates release of free fatty acids from adipose tissue, and growth hormone reduces adipocyte differentiation, triglyceride synthesis, and LPL activity (67), but the pulsatile release of both hormones becomes suppressed in prolonged critical illness. In addition, the inhibition of the melanocortin system can promote lipid uptake and triglyceride synthesis in adipose tissue (68). Thus, a single cause of the altered metabolism in adipose tissue of critically ill patients is not very likely, and a complex interplay of different affected pathways can be inferred.

Two important limitations of this study should be highlighted. The tissue biopsies used for the metabolic study were obtained from nonsurviving critically ill patients only, which may have induced a bias due to the potential confounding effects of agonal hypoxia. However, a previous study on phosphorylated signaling molecules (64), and the observation that the AMPK enzyme in liver samples from the same patients was not affected by illness (unpublished observations), argues against such bias. In addition, in the small set of in vivo subcutaneous adipose tissue biopsies from patients with prolonged critical illness, we observed the same morphological changes and macrophage staining pattern as in the postmortem biopsies. Furthermore, we demonstrated a reduction in adipocyte cell size and an increase in macrophage staining in paired in vivo adipose tissue biopsies from critically ill rabbits, very comparable to what we observed in the human biopsies. A second limitation of the study is that the tested biopsies were predominantly from normal and overweight patients; thus, we cannot extrapolate the results to obese critically ill patients. Indeed, adipose tissue from non-critically ill obese individuals markedly differs from that of lean subjects (e.g., with regard to inflammation, adipokine expression, and macrophage infiltration). However, when we compared lean subjects with overweight patients, we found no correlation between the tested parameters and BMI, except for cell size, and for this parameter the association was also present in the healthy control subjects. This suggests that adipocytes, in either normal or overweight critically ill patients, appear to act identical in response to the stress of illness, and that it may be merely the larger total fat depot that might explain the lower mortality in overweight patients versus patients with a normal BMI (3-5). However, based on some contradictory studies in which a higher mortality was already observed in obese critically ill patients (69-71), it appears, as yet, unclear at what point a higher BMI switches from being protective to malignant.

In conclusion, adipose tissue is substantially altered during critical illness, with an increased number of newly formed adipocytes and macrophage infiltration observed in in vivo- and postmortem-harvested biopsies of patients, as well as in an animal model. The larger number of small adipocytes appears to have an increased ability to take up circulating glucose and triglycerides, although this was only studied in postmortem biopsies. Such changes may render adipose tissue biologically active as a functional storage depot for these possibly toxic metabolites during critical illness, thereby contributing to survival. Hypothetically, this protective reaction may be more pronounced in critically ill patients with a larger fat depot, but whether the observed changes are also present in adipose tissue from obese and morbidly obese patients needs further thorough investigation.

Author Disclosure: None of the authors has a financial relationship with a commercial entity that has an interest in the subject of this manuscript.

Acknowledgment: The authors thank the patients, control participants, and family members for participating in the study. They are very grateful for the expert technical assistance of Prof. Raf Sciot, Lieve Ophalvens, Sarah Derde, and Eric Ververs. They wish to acknowledge Prof. Alexander Wilmer and Prof. Wouter Meersseman for their help with the collection of the biopsies.

\section{References}

1. Hart DW, Wolf SE, Herndon DN, Chinkes DL, Lal SO, Obeng MK Beauford RB, Mlcak RTRP. Energy expenditure and caloric balance after burn: increased feeding leads to fat rather than lean mass accretion. Ann Surg 2002;235:152-161.

2. Plank LD, Connolly AB, Hill GL. Sequential changes in the metabolic response in severely septic patients during the first 23 days after the onset of peritonitis. Ann Surg 1998;228:146-158.

3. Fonarow GC, Srikanthan P, Costanzo MR, Cintron GB, Lopatin M. An obesity paradox in acute heart failure: analysis of body mass index and inhospital mortality for 108,927 patients in the Acute Decompensated Heart Failure National Registry. Am Heart J 2007;153:7481 .

4. Nasraway SA Jr, Albert M, Donnelly AM, Ruthazer R, Shikora SA, Saltzman E. Morbid obesity is an independent determinant of death among surgical critically ill patients. Crit Care Med 2006;34:964-970.

5. Peake SL, Moran JL, Ghelani DR, Lloyd AJ, Walker MJ. The effect of obesity on 12-month survival following admission to intensive care: a prospective study. Crit Care Med 2006;34:2929-2939.

6. Marin P, Hogh-Kristiansen I, Jansson S, Krotkiewski M, Holm G, Bjorntorp P. Uptake of glucose carbon in muscle glycogen and adipose tissue triglycerides in vivo in humans. Am J Physiol 1992; 263:E473-E480.

7. Grunfeld C, Feingold KR. Tumor necrosis factor, cytokines, and the hyperlipidemia of infection. Trends Endocrinol Metab 1991;2:213 219

8. Tappy L, Cayeux MC, Schneiter P, Schindler C, Temler E, Jequier E, Chiolero R. Effects of lactate on glucose metabolism in healthy subjects and in severely injured hyperglycemic patients. Am J Physiol 1995;268:E630-E635.

9. Lind L, Lithell H. Impaired glucose and lipid metabolism seen in intensive care patients is related to severity of illness and survival. Clin Intensive Care 1994;5:100-105.

10. Mesotten D, Swinnen JV, Vanderhoydonc F, Wouters PJ, Van den Berghe G. Contribution of circulating lipids to the improved outcome 
of critical illness by glycemic control with intensive insulin therapy. J Clin Endocrinol Metab 2004;89:219-226.

11. Langouche L, Van den Berghe G. Glucose metabolism and insulin therapy. Crit Care Clin 2006;22:119-129. (vii.).

12. Langouche L, Vanhorebeek I, Vlasselaers D, Vander Perre S, Wouters PJ, Skogstrand K, Hansen TK, Van den Berghe G. Intensive insulin therapy protects the endothelium of critically ill patients. J Clin Invest 2005;115:2277-2286.

13. Van den Berghe G, Wilmer A, Milants I, Wouters PJ, Bouckaert B, Bruyninckx F, Bouillon R, Schetz M. Intensive insulin therapy in mixed medical/surgical intensive care units: benefit versus harm. Diabetes 2006;55:3151-3159.

14. Vanhorebeek I, De Vos R, Mesotten D, Wouters PJ, De Wolf-Peeters C, Van den Berghe G. Protection of hepatocyte mitochondrial ultrastructure and function by strict blood glucose control with insulin in critically ill patients. Lancet 2005;365:53-59.

15. Seidner DL, Mascioli EA, Istfan NW, Porter KA, Selleck K, Blackburn GL, Bistrian BR. Effects of long-chain triglyceride emulsions on reticuloendothelial system function in humans. JPEN $J$ Parenter Enteral Nutr 1989;13:614-619.

16. Smyrniotis VE, Kostopanagiotou GG, Arkadopoulos NF, Theodoraki KA, Kotsis TE, Lambrou AT, Vassiliou JG. Long-chain versus medium-chain lipids in acute pancreatitis complicated by acute respiratory distress syndrome: effects on pulmonary hemodynamics and gas exchange. Clin Nutr 2001;20:139-143.

17. Lekka ME, Liokatis S, Nathanail C, Galani V, Nakos G. The impact of intravenous fat emulsion administration in acute lung injury. $A m J$ Respir Crit Care Med 2004;169:638-644.

18. Langouche L, Vander Perre S, Van den Berghe G. Altered substrate handling in adipose tissue of critically ill patients (abstract). The Endocrine Society Annual Meeting, 10-13 June 2009, Washington, DC, and Academy Colloquium "Nutrition, Metabolism and the Brain" - Netherlands Institute for Neuroscience, 12-14 May, 2009, Amsterdam, The Netherlands.

19. Langouche L, Vander Perre S, Thiessen S, D'Hoore A, Hermans G, Kola B, Korbonits M, Van den Berghe G. Alterations in adipose tissue during critical illness: an adaptive and protective response (abstract)? International Symposium on Intensive Care Medicine, 912 March, 2010, Brussels, Belgium.

20. Van den Berghe G, Wilmer A, Hermans G, Meersseman W, Wouters PJ, Milants I, Van Wijngaerden E, Bobbaers H, Bouillon R. Intensive insulin therapy in the medical ICU. N Engl J Med 2006;354:449-461.

21. Bergmeyer HU, Bergmeyer J, Grassl M. Methods of enzymatic analysis. Vol. 8. Weinheim: Verlag Chemie; 1985.

22. Kola B, Hubina E, Tucci SA, Kirkham TC, Garcia EA, Mitchell SE, Williams LM, Hawley SA, Hardie DG, Grossman AB, et al. Cannabinoids and ghrelin have both central and peripheral metabolic and cardiac effects via AMP-activated protein kinase. J Biol Chem 2005; 280:25196-25201.

23. Weekers F, Van Herck E, Coopmans W, Michalaki M, Bowers CY, Veldhuis JD, Van den Berghe G. A novel in vivo rabbit model of hypercatabolic critical illness reveals a biphasic neuroendocrine stress response. Endocrinology 2002;143:764-774.

24. Jing K, Heo JY, Song KS, Seo KS, Park JH, Kim JS, Jung YJ, Jo DY, Kweon GR, Yoon WH, Hwang BD, Lim K, Park JI. Expression regulation and function of Pref-1 during adipogenesis of human mesenchymal stem cells (MSCs). Biochim Biophys Acta 2009;1791: 816-826.

25. Nueda ML, Baladron V, Sanchez-Solana B, Ballesteros MA, Laborda J. The EGF-like protein dlk1 inhibits notch signaling and potentiates adipogenesis of mesenchymal cells. J Mol Biol 2007;367:1281-1293.

26. Kim KA, Kim JH, Wang Y, Sul HS. Pref-1 (preadipocyte factor 1) activates the MEK/extracellular signal-regulated kinase pathway to inhibit adipocyte differentiation. Mol Cell Biol 2007;27:2294-2308.

27. Wang Y, Sul HS. Pref-1 regulates mesenchymal cell commitment and differentiation through Sox9. Cell Metab 2009;9:287-302.

28. Micklem K, Rigney E, Cordell J, Simmons D, Stross P, Turley H, Seed B, Mason D. A human macrophage-associated antigen (CD68) detected by six different monoclonal antibodies. Br J Haematol 1989;73:6-11.

29. Weisberg SP, McCann D, Desai M, Rosenbaum M, Leibel RL, Ferrante AW Jr. Obesity is associated with macrophage accumulation in adipose tissue. J Clin Invest 2003;112:1796-1808.

30. Xu H, Barnes GT, Yang Q, Tan G, Yang D, Chou CJ, Sole J, Nichols A, Ross JS, Tartaglia LA, et al. Chronic inflammation in fat plays a crucial role in the development of obesity-related insulin resistance. J Clin Invest 2003;112:1821-1830.
31. Pasarica M, Sereda OR, Redman LM, Albarado DC, Hymel DT, Roan LE, Rood JC, Burk DH, Smith SR. Reduced adipose tissue oxygenation in human obesity: evidence for rarefaction, macrophage chemotaxis, and inflammation without an angiogenic response. Diabetes 2009;58:718-725.

32. Cinti S, Mitchell G, Barbatelli G, Murano I, Ceresi E, Faloia E, Wang S, Fortier M, Greenberg AS, Obin MS. Adipocyte death defines macrophage localization and function in adipose tissue of obese mice and humans. J Lipid Res 2005;46:2347-2355.

33. Wellen KE, Hotamisligil GS. Inflammation, stress, and diabetes. J Clin Invest 2005;115:1111-1119.

34. Curat CA, Miranville A, Sengenes C, Diehl M, Tonus C, Busse R, Bouloumie A. From blood monocytes to adipose tissue-resident macrophages: induction of diapedesis by human mature adipocytes. Diabetes 2004;53:1285-1292.

35. Brownlee M. Biochemistry and molecular cell biology of diabetic complications. Nature 2001;414:813-820.

36. Kim CS, Kawada T, Yoo H, Kwon BS, Yu R. Macrophage inflammatory protein-related protein-2, a novel CC chemokine, can regulate preadipocyte migration and adipocyte differentiation. FEBS Lett 2003;548:125-130.

37. Charriere G, Cousin B, Arnaud E, Andre M, Bacou F, Penicaud L, Casteilla L. Preadipocyte conversion to macrophage: evidence of plasticity. J Biol Chem 2003;278:9850-9855.

38. Kremen J, Dolinkova M, Krajickova J, Blaha J, Anderlova K, Lacinova Z, Haluzikova D, Bosanska L, Vokurka M, Svacina S, et al. Increased subcutaneous and epicardial adipose tissue production of proinflammatory cytokines in cardiac surgery patients: possible role in postoperative insulin resistance. J Clin Endocrinol Metab 2006;91:4620-4627.

39. Leuwer M, Welters I, Marx G, Rushton A, Bao H, Hunter L, Trayhurn P. Endotoxaemia leads to major increases in inflammatory adipokine gene expression in white adipose tissue of mice. Pflugers Arch 2009; 457:731-741.

40. Shepherd PR, Kahn BB. Glucose transporters and insulin actionimplications for insulin resistance and diabetes mellitus. $N$ Engl J Med 1999;341:248-257.

41. Bouche C, Serdy S, Kahn CR, Goldfine AB. The cellular fate of glucose and its relevance in type 2 diabetes. Endocr Rev 2004;25:807-830.

42. Shikhman AR, Brinson DC, Valbracht J, Lotz MK. Cytokine regulation of facilitated glucose transport in human articular chondrocytes. J Immunol 2001;167:7001-7008.

43. Simmons RA, Flozak AS, Ogata ES. The effect of insulin and insulinlike growth factor-I on glucose transport in normal and small for gestational age fetal rats. Endocrinology 1993;133:1361-1368.

44. Ntambi JM, Miyazaki M. Regulation of stearoyl-CoA desaturases and role in metabolism. Prog Lipid Res 2004;43:91-104.

45. Semenkovich CF, Wims M, Noe L, Etienne J, Chan L. Insulin regulation of lipoprotein lipase activity in 3T3-L1 adipocytes is mediated at posttranscriptional and posttranslational levels. J Biol Chem 1989;264: 9030-9038.

46. Casaer MP, Mesotten D, Schetz MR. Bench-to-bedside review: metabolism and nutrition. Crit Care 2008;12:222.

47. Hudgins LC, Baday A, Hellerstein MK, Parker TS, Levine DM, Seidman CE, Neese RA, Tremaroli JD, Hirsch J. The effect of dietary carbohydrate on genes for fatty acid synthase and inflammatory cytokines in adipose tissues from lean and obese subjects. $J$ Nutr Biochem 2008;19:237-245.

48. Diraison F, Yankah V, Letexier D, Dusserre E, Jones P, Beylot M. Differences in the regulation of adipose tissue and liver lipogenesis by carbohydrates in humans. J Lipid Res 2003;44:846-853.

49. Ranucci M, De Toffol B, Isgro G, Romitti F, Conti D, Vicentini M. Hyperlactatemia during cardiopulmonary bypass: determinants and impact on postoperative outcome. Crit Care 2006;10:R167.

50. Taylor CT. Mitochondria and cellular oxygen sensing in the HIF pathway. Biochem J 2008;409:19-26.

51. Kola B, Boscaro M, Rutter GA, Grossman AB, Korbonits M. Expanding role of AMPK in endocrinology. Trends Endocrinol Metab 2006; 17:205-215

52. Garton AJ, Campbell DG, Carling D, Hardie DG, Colbran RJ, Yeaman SJ. Phosphorylation of bovine hormone-sensitive lipase by the AMPactivated protein kinase: a possible antilipolytic mechanism. Eur J Biochem 1989;179:249-254

53. Bonen A, Han XX, Habets DD, Febbraio M, Glatz JF, Luiken JJ. A null mutation in skeletal muscle FAT/CD36 reveals its essential role in insulin- and AICAR-stimulated fatty acid metabolism. Am J Physiol Endocrinol Metab 2007;292:E1740-E1749. 
54. Ohira M, Miyashita Y, Murano T, Watanabe F, Shirai K. Metformin promotes induction of lipoprotein lipase in skeletal muscle through activation of adenosine monophosphate-activated protein kinase. Metabolism 2009;58:1408-1414.

55. Moustaid N, Jones BH, Taylor JW. Insulin increases lipogenic enzyme activity in human adipocytes in primary culture. $J$ Nutr 1996;126:865-870.

56. Claycombe KJ, Jones BH, Standridge MK, Guo Y, Chun JT, Taylor JW, Moustaid-Moussa N. Insulin increases fatty acid synthase gene transcription in human adipocytes. Am J Physiol 1998;274:R1253-R1259.

57. Sidossis LS, Stuart CA, Shulman GI, Lopaschuk GD, Wolfe RR Glucose plus insulin regulate fat oxidation by controlling the rate of fatty acid entry into the mitochondria. J Clin Invest 1996;98:2244-2250.

58. Stralfors $\mathrm{P}$, Bjorgell $\mathrm{P}$, Belfrage $\mathrm{P}$. Hormonal regulation of hormonesensitive lipase in intact adipocytes: identification of phosphorylated sites and effects on the phosphorylation by lipolytic hormones and insulin. Proc Natl Acad Sci USA 1984;81:3317-3321.

59. Wang H, Eckel RH. Lipoprotein lipase: from gene to obesity. Am J Physiol Endocrinol Metab 2009;297:E271-E288.

60. Carpentier AC, Frisch F, Cyr D, Genereux P, Patterson BW, Giguere R, Baillargeon JP. On the suppression of plasma nonesterified fatty acids by insulin during enhanced intravascular lipolysis in humans. Am J Physiol Endocrinol Metab 2005;289:E849-E856.

61. Roberts R, Hodson L, Dennis AL, Neville MJ, Humphreys SM, Harnden KE, Micklem KJ, Frayn KN. Markers of de novo lipogenesis in adipose tissue: associations with small adipocytes and insulin sensitivity in humans. Diabetologia 2009;52:882-890.

62. Jernas M, Palming J, Sjoholm K, Jennische E, Svensson PA, Gabrielsson BG, Levin M, Sjogren A, Rudemo M, Lystig TC, et al. Separation of human adipocytes by size: hypertrophic fat cells display distinct gene expression. FASEB J 2006;20:1540-1542.

63. Bluher M, Patti ME, Gesta S, Kahn BB, Kahn CR. Intrinsic heterogeneity in adipose tissue of fat-specific insulin receptor knock-out mice is associated with differences in patterns of gene expression. $J$ Biol Chem 2004;279:31891-31901.

64. Langouche L, Vander Perre S, Wouters PJ, D'Hoore A, Hansen TK, Van den Berghe G. Effect of intensive insulin therapy on insulin sensitivity in the critically ill. J Clin Endocrinol Metab 2007;92:38903897.

65. Langouche L, Meersseman W, Vander Perre S, Milants I, Wouters PJ, Hermans G, Gjedsted J, Hansen TK, Arnout J, Wilmer A, et al. Effect of insulin therapy on coagulation and fibrinolysis in medical intensive care patients. Crit Care Med 2008;36:1475-1480.

66. Langouche L, Van den Berghe G. The dynamic neuroendocrine response to critical illness. Endocrinol Metab Clin North Am 2006;35: 777-791.

67. Schaffler A, Scholmerich J, Buechler C. The role of 'adipotropins' and the clinical importance of a potential hypothalamic-pituitary-adipose axis. Nat Clin Pract Endocrinol Metab 2006;2:374-383.

68. Nogueiras R, Wiedmer P, Perez-Tilve D, Veyrat-Durebex C, Keogh JM, Sutton GM, Pfluger PT, Castaneda TR, Neschen S, Hofmann SM, et al. The central melanocortin system directly controls peripheral lipid metabolism. J Clin Invest 2007;117:3475-3488.

69. Bercault N, Boulain T, Kuteifan K, Wolf M, Runge I, Fleury JC. Obesity-related excess mortality rate in an adult intensive care unit: a risk-adjusted matched cohort study. Crit Care Med 2004;32:9981003.

70. Winfield RD, Delano MJ, Dixon DJ, Schierding WS, Cendan JC, Lottenberg L, Lopez MC, Baker HV, Cobb JP, Moldawer LL, et al. Differences in outcome between obese and nonobese patients following severe blunt trauma are not consistent with an early inflammatory genomic response. Crit Care Med 2010;38:51-58.

71. Byrnes MC, McDaniel MD, Moore MB, Helmer SD, Smith RS. The effect of obesity on outcomes among injured patients. J Trauma 2005; 58:232-237. 